\title{
EFFECT OF DIFFERENT MINIMAL MEDIA ON POLYHYDROXYALKANOATE PRODUCED BY BACILLUSCEREUS AND ITS CHARACTERIZATION
}

\author{
Brinda Devi A. ${ }^{1}$ and Valli Nachiyar $C^{2}$ \\ ${ }^{1}$ Research Scholar,Department of Biotechnology, Sathyabama University,Chennai, India \\ ${ }^{2}$ Department of Biotechnology Sathyabama University,Chennai, India. \\ Email: 'brindadevi.a@gmail.com
}

\begin{abstract}
Polyhydroxyalkanoates (PHAs), biodegradable polymers, naturally produced by many micro organisms accumulate as energy reserves under abundant carbon and limiting nitrogen source. In this study, bacterial isolates from dairy effluent, oil dipped cloth, local mess food and oil wastes and few type cultures were screened for PHA production. The bacteria isolated from oil dipped cloth produced maximum concentration of PHA and this was later identified as Bacillus cereus by $16 \mathrm{~S}$ rDNA analysis. Maximum production of PHA (48.39\% of dry cell weight) was noticed when the bacteria was grown in Minimal medium 7 (Mm 7) containing 2\% glucose and 1\% ammonium sulphate as carbon and nitrogen sources respectively. Growth and production followed a specific pattern in which PHA production started on $4^{\text {th }}$ day reaching its maximum on day 5. Accumulated PHA granules were characterized by Sudan black staining and the FTIR spectra showed bands characteristic of Polyhydroxybutyrate (PHB).
\end{abstract}

Key words: Polyhydroxyalkanoates, Polyhydroxybutyrate, Bacillus cereus, minimal media, Sudan black staining.

\section{INTRODUCTION}

Growth in the human population has led to the accumulation of huge amounts of non-degradable waste materials across our planet. The accumulation of plastic waste has become a major concern in terms of the environment. Conventional plastics not only take many decades to be decomposed in nature, but also produce toxins during the process of degradation. For this reason, there is a special interest in producing plastics from materials that can be readily eliminated from our biosphere in an "environmental friendly" fashion (1).

Bioplastics are natural biopolymers that are synthesized and catabolized by various organisms and these materials do not cause toxic effects in the host and have certain advantages over petroleum-derived plastic 2 . Bacterial plastic is usually defined as an exciting new area of research, where naturally synthesized bacterial polymer, such as, the lipid storage material PHA is being used as raw materials for plastic based packaging materials (3). The most widely produced microbial bioplastics are polyhydroxyalkanoates (PHAs) and their derivatives (4$6)$.

Several bacteria synthesize and accumulate PHA as carbon and energy storage materials under the condition of limiting nutrients in the presence of excess carbon source (7). PHA has also been found in numerous heterotrophic and autotrophic aerobic bacteria, photosynthetic anaerobic bacteria (8), gliding bacteria (9), actinomycetes (10), cyanobacteria (11) and many other prokaryotes.This biodegradable polymer can be produced from relatively cheaper substrates such as, carbon dioxide or ethanol and also by microbes from renewable resources (12).

The main advantage of this type of polymer is that since they are of biological origin, they degrade naturally and completely to $\mathrm{CO}_{2}$ and $\mathrm{H}_{2} \mathrm{O}$ under natural environment by the enzymatic activities of microbes.

The composition of PHA depends on the micro-organisms and nature of the carbon source allowing the formation of the new polymers with different physicochemical properties; hydrocarbons, short or mid-chain fatty acids, or hydrophilic carbon sources such as glucose have been supplied $(5,13)$.

\section{MATERIALS AND METHODS}

\section{A. Microorganisms}

Microorganisms for PHA production were isolated from different sources like dairy effluent, oil dipped cloth and local mess food and oil waste. Type cultures were also purchased from MTCC and they include Pseudomonas fluorescence and Pseudomonas 
aeruginosa. The selected isolate producing high concentration of PHA was selected for further studies.

\section{B. Molecular characterisation of the PHA producing bacteria}

The sequence of the 16s rRNA gene has been widely used as a phylogenetic marker to study genetic relationships between different strains of bacteria. The analysis of this gene can therefore be considered as a standard method for the identification of bacteria at the family, genus and species levels $(14,15)$ and has in fact been included in the latest edition of Bergey's Manual of Systematic Bacteriology (16). Genomic DNA was isolated from the pure culture pellet and the approximately $1.4 \mathrm{~kb}$ fragments corresponding to $16 \mathrm{~s}$ rRNA was amplified using universal primers, high fidelity PCR polymerase. The PCR product was sequenced bi-directionally using the forward and reverse primer. This sequence was compared with the 16s rDNA sequence data from strains available at the public databases (Genbank, EMBL and DDBJ) using BLASTN sequence match routines $(17,18)$.

The PHA producing bacterium was identified as Bacilli sp using the standard microbiological and biochemical tests. This was further characterized by 16s rDNA analysis. The bacterial DNA was isolated and the 16s rDNA sequence was amplified and sequenced. The 16s rDNA sequence of the PHA producing bacterium obtained was compared with the non-redundant BLAST database to obtain the sequences that displayed maximum similarity.

\section{Culture Conditions}

Screening studies for PHA production were carried out in duplicate in $250 \mathrm{ml}$ flasks containing 50 $\mathrm{ml}$ nutrient broth. The medium was inoculated with $2 \%$ inoculum precultured for $12 \mathrm{~h}$. The inoculated media were incubated in an incubator shaker at $150 \mathrm{rpm}$ at $32^{\circ} \mathrm{C}$. Cells were harvested everyday for 5 days for PHA quantification by taking $10 \mathrm{ml}$ of culture media and centrifuging at 10,000 rpm for $10 \mathrm{~min}$. The bacterial growth was monitored by taking the dry weight of lyophilized cells.

Ten different minimal media (namely Mm1, MmM2 to Mm10) containing the following components and $10 \mathrm{ml} / /$ of trace element solution (25) respectively were designed for optimizing the production of PHA by the isolated Bacillus cereus.

\section{PHA Quantification}

PHA in the bacterial cell pellets was extracted and quantified by the methods described by Kessler et al 2001(5) and Law \& Slepecky 1960 (22) respectively.. The pellets obtained after centrifugation were pretreated with acetone and diethyl ether to remove impurities and to make the pellets dry. To this $2 \mathrm{ml}$ boiling chloroform was added followed by filtration using Whattman No1 filter paper. The dissolved PHA in the chloroform was precipitated using methanol. This solution was centrifuged at $4500 \mathrm{rpm}$ for $15 \mathrm{~min}$ and the precipitated obtained was redissolved in hot choloroform and evaporated to dryness using a water bath. $5 \mathrm{ml}$ of Conc. Sulphuric acid was added to the tubes and were kept for boiling at $100^{\circ} \mathrm{C}$ for $10 \mathrm{~min}$ and cooled. The absorbance was measured at $235 \mathrm{~nm}$ against Conc. $\mathrm{H}_{2} \mathrm{SO}_{4}$ as blank.

\section{E. Characterization of PHA granules accumulation by Sudan black staining}

The pure strains were screened for the presence of Polyhydroxybutyrate granule using Sudan black staining method and analysed (21). The Sudan Black powder $(0.3 \mathrm{~g})$ was separately weighed and mixed with $100 \mathrm{ml}$ of $70 \%$ ethanol. Safranin powder $(0.5 \mathrm{~g})$ was separately weighed and mixed with $100 \mathrm{ml}$ of distilled water.

A thick smear was prepared from the culture suspension in a clean glass slide. A few drops of sudan black solution was placed on the fixed preparation and allowed to react for 10 minutes. The smear was washed with distilled water and then allowed to react with safranin solution for 10 seconds. The smear was then rinsed with distilled water and air dried. The smear was then observed under oil immersion objective for dark purple colour granules and pink colour cytoplasm. The positive cultures showing dark purple colour PHB granules were maintained separately in nutrient agar slants and used for further studies.

\section{F. FTIR Analysis}

To identify the type of PHA that was produced by the bacteria FTIR analysis was carried in Perkin Elmer IR Spectrophotometer. The sample in chloroform was applied as a smear over the $\mathrm{NaCl}$ block and was analysed 
Table 1. Components of Minimal media

\begin{tabular}{|c|c|c|c|c|c|c|c|c|c|c|}
\hline \multirow{2}{*}{ Media Components $(\mathrm{g} / \mathrm{l})$} & \multicolumn{10}{|c|}{ Media Trial } \\
\hline & Mm1 & Mm2 & Mm3 & Mm4 & Mm5 & Mm6 & Mm7 & Mm8 & Mm9 & Mm10 \\
\hline $\mathrm{K}_{2} \mathrm{HPO}_{4}$ & 10.5 & 0.5 & 1.5 & 0.5 & 0.1 & 1.0 & 3 & 10.5 & 2.65 & 2.65 \\
\hline $\mathrm{KH}_{2} \mathrm{PO}_{4}$ & 4.5 & 0.5 & - & 0.5 & 0.4 & - & - & 4.5 & - & - \\
\hline $\mathrm{MgSO}_{4}$ & 0.1 & 0.2 & 0.4 & - & - & - & - & 0.1 & 0.2 & 0.2 \\
\hline $\mathrm{NaCl}$ & - & 0.2 & - & - & 0.1 & - & 0.5 & - & - & - \\
\hline $\mathrm{CaCl}_{2}$ & - & 0.04 & - & - & $\overline{-}$ & - & - & $\overline{-}$ & 7.8 & - \\
\hline $\mathrm{CH}_{3} \mathrm{COOH}$ & - & - & 20 & - & - & 2.0 & - & - & - & - \\
\hline Yeast extract & - & - & - & 2.0 & 0.4 & - & 10 & - & - & 10 \\
\hline$\left(\mathrm{NH}_{4}\right)_{2} \mathrm{SO}$ & - & - & - & 0.8 & $\overline{-}$ & $\overline{-}$ & - & 3 & - & 5 \\
\hline $\mathrm{MgSO}_{4} \cdot 7 \mathrm{H}_{2} \mathrm{O}$ & - & - & - & 0.02 & 0.2 & 0.4 & 0.2 & - & - & - \\
\hline $\mathrm{CaCl}_{2} \cdot 2 \mathrm{H}_{2} \mathrm{O}$ & - & - & - & 0.053 & - & - & - & - & - & - \\
\hline Mannitol & - & - & - & - & 10 & - & - & - & - & - \\
\hline$\left(\mathrm{NH}_{4}\right)_{2} \mathrm{HPO}_{4}$ & - & - & - & - & - & 0.75 & 1 & - & - & - \\
\hline $\mathrm{Na}_{2} \mathrm{HPO}_{4}$ & - & - & - & - & - & - & 6 & $\overline{-}$ & 3.8 & 5 \\
\hline Casein & - & - & - & - & - & - & 5 & - & - & - \\
\hline $\mathrm{NH}_{4} \mathrm{Cl}$ & - & - & - & - & - & - & - & - & 0.5 & - \\
\hline $\mathrm{FeCl}_{3}$ & - & - & - & - & - & - & - & - & 0.97 & - \\
\hline $\mathrm{NiCl}_{3}$ & - & - & - & - & - & - & - & - & 0.118 & - \\
\hline $\mathrm{CuSO}_{4} \cdot 5 \mathrm{H}_{2} \mathrm{O}$ & $\overline{-}$ & - & - & - & - & $\overline{-}$ & - & - & 0.15 & - \\
\hline Peptone & $\overline{-}$ & - & - & - & $\overline{-}$ & $\overline{-}$ & - & - & - & 10 \\
\hline Fructose (C-source) & 20 & 20 & 20 & 20 & 20 & 20 & 20 & 20 & 20 & 20 \\
\hline$\left(\mathrm{NH}_{4}\right)_{2} \mathrm{SO}_{4}(\mathrm{~N}-\mathrm{Source})$ & 10 & 10 & 10 & 10 & 10 & 10 & 10 & 10 & 10 & 10 \\
\hline
\end{tabular}

\section{RESULTS AND DISCUSSIONS}

Biodegradable Plastics are new and very interesting because of their actual utilization by bacteria. Bacterial plastic is usually defined as an exciting new area of research where naturally synthesized bacterial polymer such as lipid storage materials PHB is being used as raw material for plastic based packaging material (23).

The selected isolate showing maximum production of PHA (Fig 1) was identified as Bacilli sp on the basis of their morphological and biochemical characteristics. The organism was found to be gram positive rod shaped, spore formers (Fig 2).
All the sequences reported by BLAST revealed that the bacterial species showed a very high percentage of similarity $(99 \%)$ with the sequences of Bacillus cereus, with a reasonably high score and e-value being zero (Table 3).

Time course of growth and PHA production are shown in (Fig. 3). The PHA production started from day 1 but appreciable concentration was obtained from day 4 reaching a maximum on $5^{\text {th }}$ day. This result is in accordance with previous reports (24) which stated that the production of PHA takes place under nutrient limiting conditions.

The efficiency of Bacillus cereus to produce more PHA was checked with different minimal media (Mm1, 


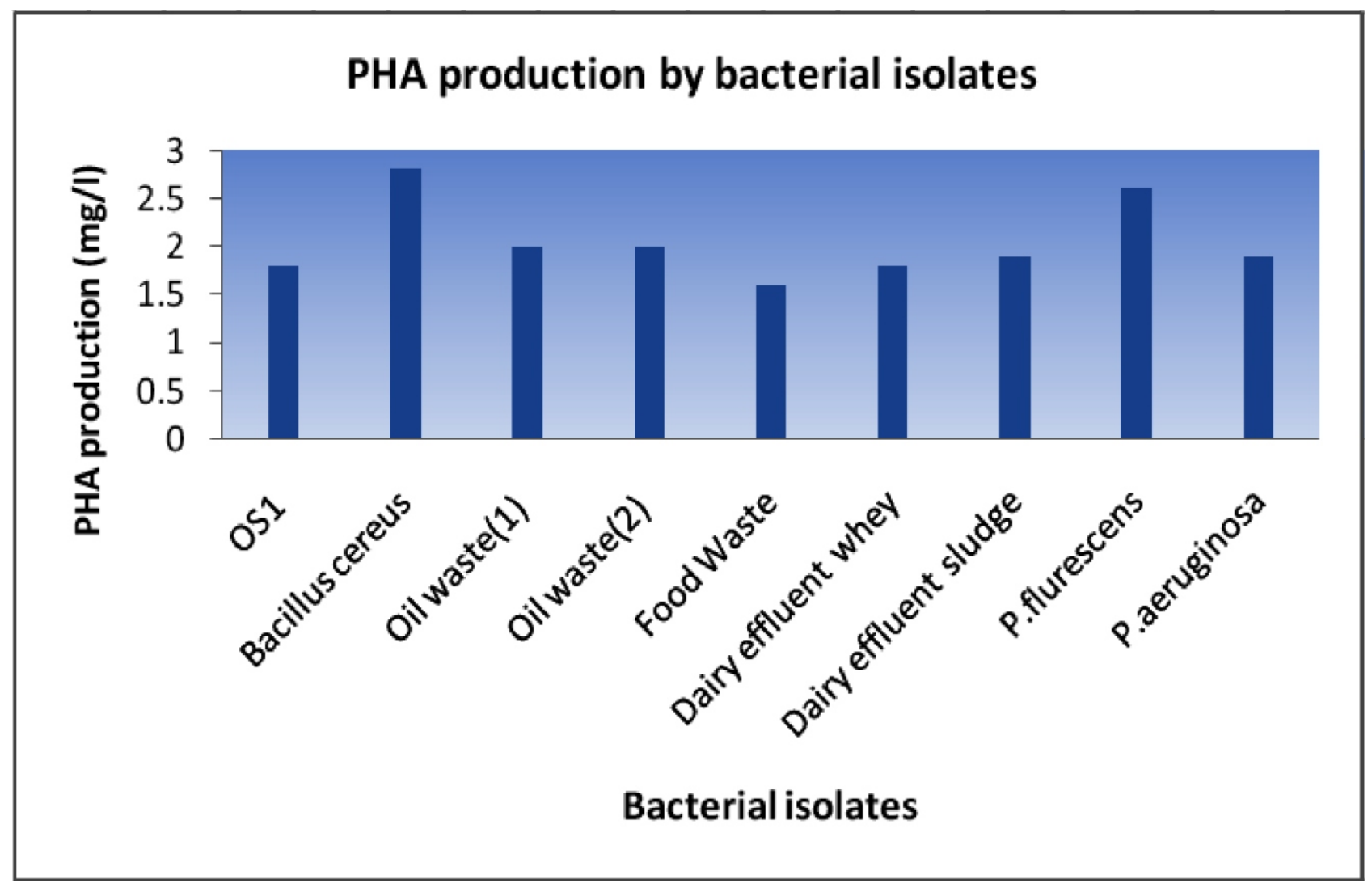

Fig. 1. PHA production by bacterial isolates

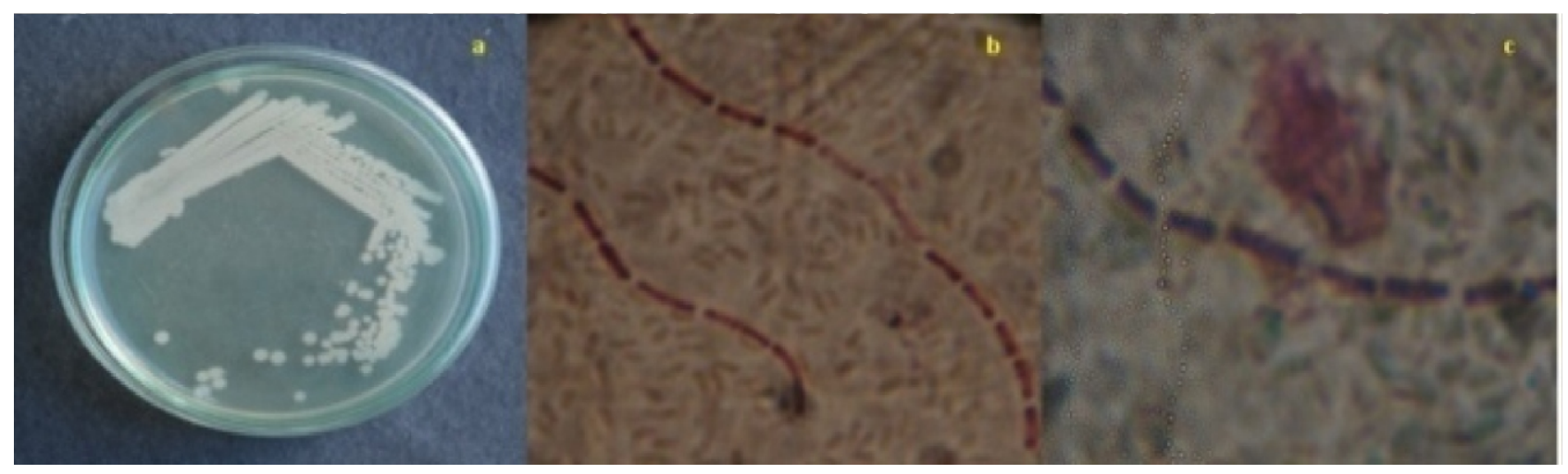

Fig. 2. a. Quadrant streaked Plate showing Bacillus cereus b. Gram Staining c. Endospore staining.

Table 2. 16s rDNA SEQUENCE SIMILARITY REPORT OF $\mathrm{OS}_{2}$

\begin{tabular}{|l|l|c|c|c|}
\hline Accession & \multicolumn{1}{|c|}{ Description } & Query coverage & E value & Max identity \\
\hline NC_003909.8 & Bacillus cereus ATCC 10987, complete genome & $97 \%$ & 0.0 & $97 \%$ \\
\hline NC_005957.1 & $\begin{array}{l}\text { Bacillus thuringiensis serovar konkukian str. 97-27 } \\
\text { chromosome, }\end{array}$ & $96 \%$ & 0.0 & $97 \%$ \\
\hline
\end{tabular}




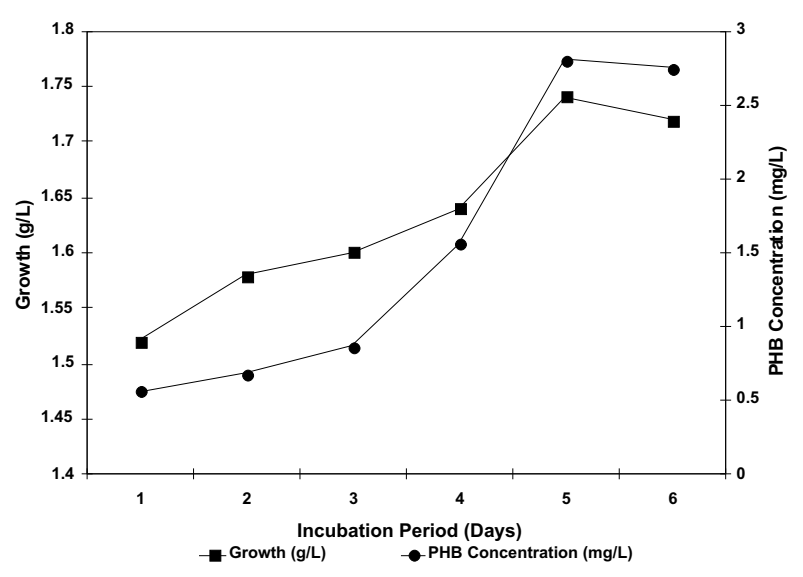

Fig. 3. Time course of PHA production

Mmm2 to MM10) (Table.3.) and the results have shown that the organism produced more PHA (48.39\% of dry weight) in $\mathrm{Mm} 7$ that contained $1 \%$ ammonium sulphate as inorganic nitrogen source, $2 \%$ fructose as carbon source and $1 \mathrm{ml}$ of trace element solution (Table.1) (25).

Table. 3. Effect of different minimal media on PHA production

\begin{tabular}{|c|c|c|c|c|}
\hline SI.No & $\begin{array}{c}\text { Minimal } \\
\text { media } \\
\text { trials }\end{array}$ & $\begin{array}{c}\text { Biomass } \\
\text { (g/l) }\end{array}$ & $\begin{array}{c}\text { PHA } \\
\text { Yeild } \\
\text { (g/l) }\end{array}$ & $\begin{array}{c}\text { PHA } \\
\text { Yeild } \\
(\mathbf{\%})\end{array}$ \\
\hline 1 & Mm1 & 2.2 & 0.29 & 9.5 \\
\hline 2 & Mm2 & 0.6 & 0.17 & 28.3 \\
\hline 3 & $\mathrm{Mm3}$ & - & - & - \\
\hline 4 & $\mathrm{Mm4}$ & 1.6 & 0.26 & 16.25 \\
\hline 5 & $\mathrm{Mm5}$ & 0.6 & 0.12 & 20.0 \\
\hline 6 & $\mathrm{Mm6}$ & - & - & - \\
\hline 7 & $\mathrm{Mm7}$ & 0.6 & 0.21 & 48.39 \\
\hline 8 & $\mathrm{Mm8}$ & 0.4 & 0.16 & 40.0 \\
\hline 9 & $\mathrm{Mm9}$ & 0.8 & 0.21 & 26.5 \\
\hline 10 & $\mathrm{Mm10}$ & 0.6 & 0.22 & 36.6 \\
\hline
\end{tabular}

Our strain was tested positive for presence of lipophilic PHA granules. PHA granules were observed by Sudan Black staining method. PHA granules were observed dark gray-black in the pink-sole red vegetative cells (fig.4) by using Sudan black staining method (26).

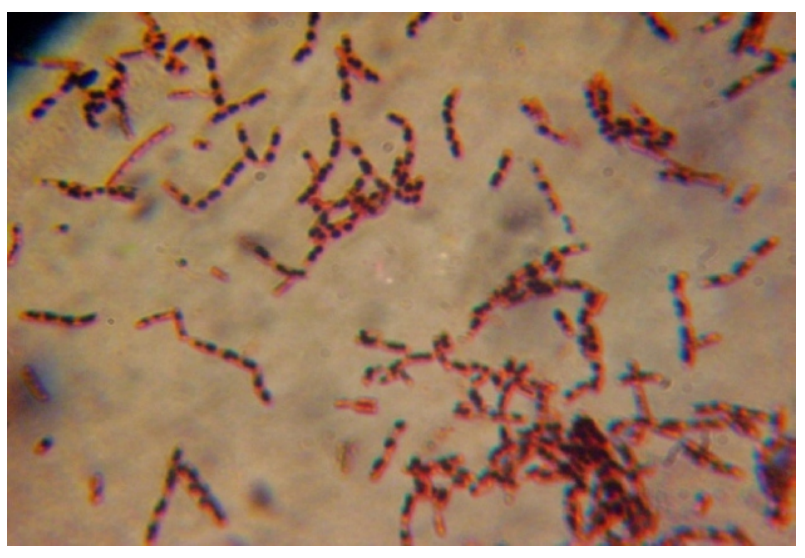

Fig. 4. Sudan Black staining for PHA

FTIR analysis of PHA produced by Bacillus $s p$ isolated from oil soaked cloth showed bands characteristic of PHB (fig.5). The band found at $1725.52 \mathrm{~cm}-1$ corresponds to ester carbonyl group $(C=O)$ which is comparable to PHA being produced by Pseudomonas aeruginosa, (26) Azotobacter vinelandii \& Pseudomonas mendocina (27) and from Alcaligens eutrophus (28).

The band found at $1378.91 \mathrm{~cm}-1$ is the equivalent for $\mathrm{CH} 3$ groups and the band at $1271.59 \mathrm{~cm}-$ corresponds to the $-\mathrm{CH}$ group. Also bands of minor relevance, such as those found at $3430 \mathrm{~cm}-1$, originated due to water adsorption onto the sample, are found in all spectra (28).

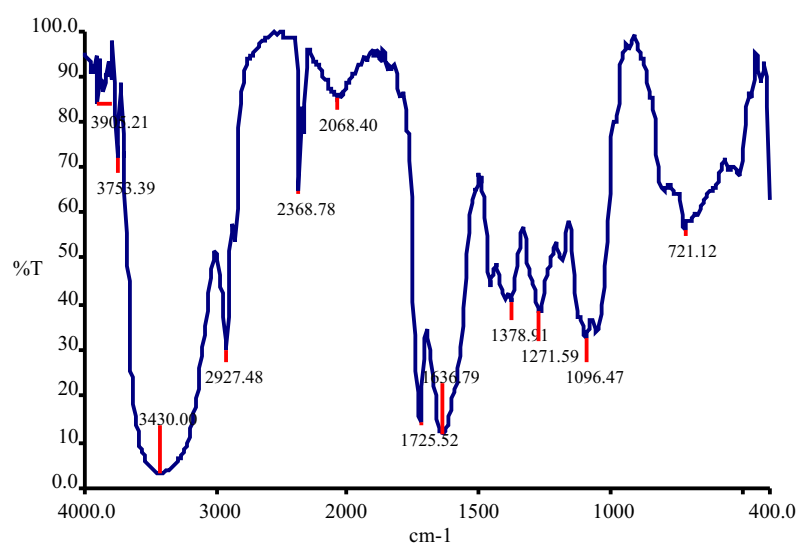

Fig. 5. FTIR spectrum of Biopolymer produced by Bacillus cereus

\section{CONCLUSION}

In spite of excellent progress made in biopolymer production, cost effective PHA production appears to be a realistic goal for the future. In this study, an 
attempt has been made to isolate bacteria capable of producing PHA which was later identified as Bacillus cereus and characterized the PHA granule accumulation by staining and FTIR as PHB. The growth follows a specific pattern and the appreciable production of PHB started on day 4 reaching maximum on day 5. Optimization studies indicated that $\mathrm{Mm} 7$ supported maximum production of PHA by Bacillus cereus.

\section{ACKNOWLEDGEMENT}

We sincerely thank Sathyabama university for providing a great opportunity and support to carry out this work.

\section{REFERENCES}

[1] R. A. Gross and B. Kalra., 2007, Biodegradable polymers for the environment. Science. vol.297, pp. 803-807.

[2] A.Steinbuchel and B.Fuchtenbusch, 1998, Bacterial and other biological systems for Polyester Production. Trends in Biotechnol., vol.16, pp.419-427..

[3] M. T.Madigan, Martinko and J Parker.,1997, Brock Biology of Microorganisms (Bacterial Plastics). Prentice Hall In, Ink London., vol.588.

[4] L. L Madison and G. W.Huisman., 1999, Metabolic Engineering of Poly(3-Hydroxyalkanoates). Microbiol Mol Biol. Rev., vol.63, pp.21-53.

[5] B.Kessler, R Weusthuis., Witholt and G.Eggink., 2001, Production of Microbial Polyesters, Fermentation and Down Stream Process. Adv Biochem Eng., vol.71, pp.159-82.

[6] Y. B. Kim and R. W Lenz., 2001, Polyesters from Microorganisms. Adv Biochem Eng Biotechnol., vol.71, pp.51-79.

[7] D. Byron.,1987, Polymer Synthesis by Microorganisms: Technology and Economics. Trends Biotechn., vol. 5, pp. 246-50.

[8] E. A. Dawes and S P. J.enior., 1973, The Role and Regulation of Energy Reserve Polymers in Microorganisms. Adv. microb, physiol., vol. 10, pp. 135-266.

[9] E.G Pringsheim and W.Wiessner.,1963, Minimum requirements for heterotrophic growth and reserve substance in Beggiatoa. Nature. vol. 197, pp. 102.

[10] L. V Kannan. and Z.Rehacek.,1970, Formation of Poly-â-hydroxybutyrate by Acinomycetes. Indian $\mathrm{J}$. Biochem. Vol. 7, pp. 126-129.

[11] N. G. Carr.,1996, The Occurrence of Poly-beta-hydroxybutyrate in the blue-green alga chlorogloea fritschii. Biochem, Biophy, ACTA.vol. 120, pp.308-310.

[12] W.Q.Chowdhury.,1996, Biosynthesis of poly-â-hydroxybutyric acid (PHB) in the marine photosynthetic bacterium Rhodovulum sulphidophilum strain W-1S. Ph.D. Thesis laboratory of Biofunctional Engineering, Faculty of Pharmaceutical Science , Osaka University, Japan.

[13] Steinbüchel, H.Valentin., 1995, Diversity of bacterial polyhydroxyalkanoic acids. FEMS Microbiol Lett. vol. 128, pp. 219-28.

[14] Vijay C Verma, Ravindra N Kharwar, Alan C Gange., 2010, Biosynthesis of antimicrobial silver nanoparticles by the endophytic fungus Aspergillus clavatus. Nanomedicine, vol. 5, pp. 3340 .

[15] N. S. Ravi Raja, G. L. Maria, K. R. Sridhar., 2006, Antimicrobial evaluation of endophytic fungi inhabiting plants of western ghats of India. Eng. Lifescience vol. 6, pp. $515-520$.

[16] CR Woese., 1987 Microbiol Rev, vol51, pp. 221-271.

[17] Garrity G Springer., 2005, AAVV: Bergey's Manual of Systemic Bacteriology, Vol 2.

[18] R.E.L. Procópio, W.L. Araújo, W. Maccheroni Jr., J.L. Azevedo., 2009, Characterization of an endophytic bacterial community associated with Eucalyptus spp. Genetics and Molecular Research vol. 8 (4), pp. 1408-1422.

[19] H Zhang, V Obias, K Gonyer, D Dennis.,1994, Production of polyhydroxyalkanoates in sucrose-utilizing recombinant Escherichia coli and Klebsiella strains. Applied and Environmental Microbiology Vol. 60(4) pp. 1198-1205.

[20] A.A. Khardenavis , M. Suresh Kumar , S.N. Mudliar T. Chakrabarti., 2007, Biotechnological conversion of agro-industrial wastewaters into biodegradable plastic, poly beta-hydroxybutyrate. Bioresour Technol.vol. 98(18).pp. 3579-84.

[21] Q. Das, J.U. Chowdhury, M.N. Anwar., 2004, Isolation, Purification and Characterization of Biodegradable Polymer Producing Bacteria Listeria murrayi. Pakistan Journal of biological Sciences Vol.7(11). Pp. 2018-2021.

[22] John H. Law and Ralph A. Slepecky., 1960, Assay of poly-13- Hydroxybutyric Acid, Journal of Bacteriology, vol.82, pp. 33-36.

[23] Q. Das, J. U. Chowdhury and M. N Anwar., 2004, Isolation, purification and characterization of Biodegradable Polymer producing Bacteria Listeria Murrayi. Pak. J. of Biol. Sci .,vol. 7(11) pp. 2018-2021.

[24] Kanokphorn Sangkharak \& Poonsuk Prasertsan., 2008, Nutrient optimization for production 
ofpolyhydroxybutyrate from halotolerant photosynthetic bacteria cultivated under aerobic-dark condition, Electronic Journal of Biotechnology, vol. 11.

[25] Ramachander Merugu, S. Girisham and S.M.Reddy., 2010, Production of PHB (PolyHydroxyButyrate) by Rhodopseudomonas palustris KU003 under nitrogen limitation. International Journal of Applied Biology and Parmaceutical Technology, vol. 1(2) pp. 676-678.

[26] Nur Ceyhan and Guven Ozdemir., 2011, Poly-hydroxybutyrate (PHB) production fromdomestic wastewater using Enterobacteraerogenes12Bi strain. African Journal of Microbiology ResearchDepartment of Biology, Vol. 5(6) pp. 690-702.

[27] Nazia Jamil and Nuzhat Ahmed., 2008, Production of Biopolymers by Pseudomonas aeruginosa isolated form marine source. Brazilian Archives of Biology and Technology, vol. 51, pp. 457-464.

[28] K. Hong, S. Sun, W. Tian, G.Q. Chen, and W. Huang., 1999, A rapid method for detecting bacterialpolyhydroxyalkanoates in intact cells by Fourier transform infrared spectroscopy. Applied Microbiology and Biotechnology vol. 51, pp. 523-526.

[29] Senthil Kumar and G. Prabhakaran., 2006, Production of PHB (bioplastics) using bio-effluentas substrate by Alcaligens eutrophus. Indian Journal of Biotechnology, vol. 5, pp. 76-79.

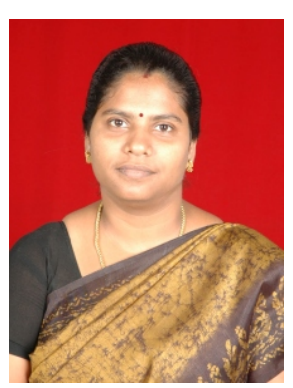

The author is a research scholar working in Sathyabama university specialized in Biochemistry. 